\title{
The Uruguay Round and the Improvements to the Gatt Dispute Settlement Rules and Procedures
}

Jean-Gabriel Castel

Osgoode Hall Law School of York University, castel@fake.osgoode.yorku.ca

Source Publication:

International and Comparative Law Quarterly. Volume 38, Issue 4 (1989), p. 834-849.

Follow this and additional works at: https://digitalcommons.osgoode.yorku.ca/scholarly_works (c) (1) $(9)$

This work is licensed under a Creative Commons Attribution-Noncommercial-No Derivative Works 4.0 License.

\section{Recommended Citation}

Castel, Jean-Gabriel. "The Uruguay Round and the Improvements to the Gatt Dispute Settlement Rules and Procedures." International and Comparative Law Quarterly 38.4 (1989): 834-849.

This Article is brought to you for free and open access by the Faculty Scholarship at Osgoode Digital Commons. It has been accepted for inclusion in Articles \& Book Chapters by an authorized administrator of Osgoode Digital Commons. 


\title{
THE URUGUAY ROUND AND THE IMPROVEMENTS TO THE GATT DISPUTE SETTLEMENT RULES AND PROCEDURES
}

\author{
J.-G. CASTEL ${ }^{*}$
}

\section{INTRODUCTION}

IT is generally agreed that the GATT system of settlement of trade disputes has worked relatively well since its creation in 1948. Over the years it has been improved on a number of occasions. However, today most members of the GATT are of the opinion that further improvements are necessary to make the system more flexible, efficient and effective. The procedures should be strengthened and some of the rules should be made clearer. In other words, there are shortcomings in the system itself and in the way in which it is operated. A better system of dispute settlement would eliminate other, less legitimate methods of resolution of disputes, especially resort to "voluntary restraints" agreements, "orderly marketing" agreements and unilateral action in the form of retaliatory measures in national trade legislation. For these reasons, the members of the GATT decided to review the rules and procedures of the dispute settlement process and to appoint a Negotiating Group on Dispute Settlement, at the Uruguay Round of negotiations that began at Punta del Este on 15 September 1986. In 1988 this group proposed a number of improvements which served as a basis for those which the Trade Negotiations Committee, meeting at Montreal on 9 December 1988 at the ministerial level, recommended for approval by the Contracting Parties ${ }^{1}$ on a trial basis.

The purpose of this article is to describe very briefly the existing system of dispute settlement and, in the light of criticisms addressed to it, examine the new improvements.

\footnotetext{
* Professor of International Business Law, Osgoode Hall Law School, York University, Toronto.

1. When the members of the GATT act collectively they are referred to as Contracting Parties in italics.
} 
II. THE PRESENT SYSTEM

\section{A. General Survey of the GATT System}

\section{Relevant provisions}

The GATT contains several articles, with clauses dealing with the resolution of disputes. ${ }^{2}$ However, Articles XXII and XXIII supplemented by the 1979 Understanding Regarding Notification, Consultation, Dispute Settlement and Surveillance, ${ }^{3}$ and the 1982 Ministerial Declaration on Dispute Settlement are the most important. ${ }^{4}$

\section{Brief analysis of relevant provisions}

(a) Consultations. Article XXII as amended in 1955 provides for consultations with respect to any matter affecting the operation of the GATT. Contracting parties are invited to solve their disputes by bilateral consultations and, if this fails, by the conciliatory intervention of the Contracting Parties. ${ }^{5}$ This is the diplomatic solution. Although working parties may be established under this Article, contracting parties have resorted to this procedure on only ten occasions between 1948 and 1986.

The 1979 Understanding adds that contracting parties undertake to respond to requests for consultations promptly and to attempt to conclude them expeditiously with a view to reaching mutually satisfactory conclusions. ${ }^{6}$

2. E.g. Arts.XIX (safeguards), XXVII (modification of schedules of concessions), XXV.5 (waivers). For a complete list of the 19 clauses in the GATT which oblige the disputants to resolve differences by consultations, see J. H. Jackson, World Trade and the Law of GATT (1969), p.164. The text of the GATT may be found in (1969) IV B.I.S.D.

3. (1978-79) B.I.S.D., 26th Supp. 210.

4. (1982) B.I.S.D., 29th Supp. 13. See also 1984 Decision which completed and clarified the 1979 Understanding on certain questions and contains directives applicable on a one-year trial basis especially with respect to a short roster of non-governmental experts qualified to serve as panelists: Action by Contracting Parties on Dispute Settlement Procedures (1985) B.I.S.D., 31st Supp. 9.

5. (1955) B.I.S.D., 3rd Supp. 250. Art.XXII provides as follows:

"Consultation:

1. Each contracting party shall accord sympathetic consideration to, and shall afford adequate opportunity for consultation regarding, such representations as may be made by another contracting party with respect to any matter affecting the operation of this Agreement.

2. The Contracting Parties may, at the request of a contracting party, consult with any contracting party or parties in respect of any matter for which it has not been possible to find a satisfactory solution through consultation under paragraph 1."

6. Para.4. Note that any contracting party requesting consultations under Art.XXII.2 must inform the Director-General of the GATT to allow notification of all other contracting parties. 1958 Decision (1959) B.I.S.D., 4th Supp. 24. 
(b) Nullification or impairment. A contracting party may have recourse to the procedures provided for by Article XXIII when it considers that any benefit accruing to it directly or indirectly under the GATT is being nullified or impaired or that the attainment of any objective of the GATT is being impeded as a result of: ${ }^{7}$

(a) the failure of another contracting party to carry out its obligations under this Agreement, or

(b) the application by another contracting party of any measure, whether or not it conflicts with the provisions of this Agreement, or

(c) the existence of any other situation.

A presumption exists that a breach of the rules of the GATT has an adverse impact on other contracting parties, and in such a case it is up to the contracting party against which the complaint is made to rebut the charge.$^{8}$ The object is to stop the violation of agreed-upon rules in order to preserve the integrity of the GATT. Emphasis is placed on adjudication.

"If a contracting party bringing an Article XXIII case, claims that measures which do not conflict with the provisions of the General Agreement have nullified or impaired benefits accruing to it under the General Agreement, it will be called upon to provide a detailed justification." ${ }^{, 9}$ The complainant must prove that a benefit accruing to it under the GATT has been nullified or impaired. In this case the emphasis is placed more on negotiation than on adjudication since no agreed-upon rules are involved.

Bilateral consultations between the disputants under Articles XXII, ${ }^{10}$ XXIII. $1,{ }^{11}$ or XXXVIII. 2 and $5^{12}$ in order to obtain a satisfactory adjustment of the matter must precede recourse to the dispute settlement procedures found in Article XXIII.2. Thus, when the contracting parties are unable to resolve their dispute through consultation, negotiation or conciliation, ${ }^{13}$ the aggrieved party ${ }^{14}$ may request the Council of the GATT to appoint a panel to adjudicate such dispute. Although there is no legal requirement, a request for the establishment of a panel will usually be granted by the Council in accordance with "standard practice" of the GATT, unless the request is opposed by the other party.

7. Art.XXIII.1.

8. 1979 Understanding, Annex, para.5.

9. Ibid. Note that the concept of nullification or impairment is related to the expectations of a contracting party.

10. 1960 Decision (1961) B.I.S.D., 9th Supp. 19.

11. 1979 Understanding, para.6.

12. Art.XXXVII deals with commitments to less-developed contracting parties.

13. 1979 Understanding, para. 8.

14. Private persons have no standing under the GATT. They must act through their governments. 
The use of the dispute settlement procedures must not be intended or considered as a contentious act and all parties must engage in these procedures in good faith in an effort to resolve the dispute. ${ }^{15}$

The panel, pursuant to its terms of reference, will investigate the dispute in the light of the rules of the GATT, hear the arguments of the parties concerned and make such findings as will assist the Contracting Parties in making recommendations or rulings. ${ }^{16}$ Since the 1982 Ministerial Declaration on Dispute Settlement was made, no more than 12 months have elapsed between the decision of the Council to establish a panel and its adoption of the panel report. On average, panels have completed their reports within six months. ${ }^{17}$ In cases of urgency, the panel should deliver its report within three months following its establishment. ${ }^{18}$

It is always possible for the parties to the dispute to reach a settlement before the panel submits its report to the Council, in which case it is the end of the matter. ${ }^{19}$

The panel may, ${ }^{20}$ if nullification or impairment is found, recommend that the offending measure be withdrawn, ${ }^{21}$ or if this cannot be done immediately, that the injured party be compensated, for instance by lower tariffs until the withdrawal takes place. ${ }^{22}$ The report containing the findings and recommendations or rulings must be given prompt consideration and approval by the Council which is empowered to act on behalf of the Contracting Parties in order to acquire legal force. ${ }^{23}$ Adoption of the report and action taken pursuant to it within a reasonable period of time are decided by consensus. ${ }^{24}$ Thus, any contracting party, including the party which is the object of the recommendations or rul-

15. 1979 Understanding, para.9. The function of Art.XXIII.2 is to encourage the parties to settle their dispute.

16. Idem, para.16.

17. Idem, para.20: the time required by panels varies with the particular case. Also 1982 Ministerial Declaration on Dispute Settlement, para.(vi). The panels are composed of three to five independent experts agreed upon by the parties to the dispute or selected by the Director-General: 1979 Understanding, para.11; Annex, para.6(iii). Also 1984 Decision. The panel's composition and terms of reference must, in principle, be determined within 30 days following the decision to establish it.

18. 1979 Understanding, para.20.

19. Idem, para.17. The report of the panel may be confined to reporting that a solution has been reached.

20. Idem, Annex, paras.3 and 6(viii); 1982 Ministerial Declaration on Dispute Settlement, para.(v).

21. Idem, Annex, para.4. Note that idem, paras. 2 and 3 provide for publication and notification of trade measures possibly in advance of implementation. Thus, if the measures were to violate GATT obligations, a dispute could be avoided before it arose by consultations leading to the withdrawal of the measures.

22. Idem, Annex, para.4.

23. Idem, Annex, para.1, fn.1.

24. 1982 Ministerial Declaration on Dispute Settlement, para.(x). 
ings, can block the adoption of the report. However, obstruction in the process of dispute settlement must be avoided. ${ }^{25}$ Consensus does not mean unanimity especially in view of Article XXV.4 of the GATT, which states that, except as otherwise provided, decisions of the Contracting Parties are taken by a majority of the votes cast.

The Contracting Parties will keep under surveillance any matter on which they have made recommendations or rulings to make sure that implementation takes place within a reasonable period of time. ${ }^{26}$. If the recommendations or rulings are not implemented, the aggrieved contracting party may seek the authorisation of the Council to take retaliatory action against the offending party. ${ }^{27}$ Usually, this means the suspension, on a discriminatory basis, of the application of concessions $v i s-a ̀-v i s$ the other member country concerned in order to restore the negotiated balance of rights and obligations under the GATT:

If the application to any contracting party of any concession or other obligation is in fact suspended, that contracting party shall then be free, not later than sixty days after such action is taken, to give written notice to the Executive Secretary to the Contracting Parties of its intention to withdraw from this Agreement and such withdrawal shall take effect upon the sixtieth day following the day on which such notice is received by him. ${ }^{28}$.

As stated by one authority: ${ }^{29}$

One of the basic objectives of any dispute procedure in GATT has been the effective resolution of the dispute rather than "punishment", or imposing a "sanction". or obtaining "compensation". The prime objective has been stated to be the "withdrawal" of a measure inconsistent with the General Agreement.

Today, in spite of the progressive codification of the basic procedures for the settlement of disputes by third party adjudication, consultations and conciliation leading to an amicable settlement through diplomatic negotiations are still preferred by the contracting parties. Thus, the major characteristic of the GATT system of settlement of disputes is the conciliatory character of the procedures. The objective is to redress

25. Ibid.

26. 1979 Understanding, para.22; 1982 Ministerial Declaration on Dispute Settlement, para.(viii).

27. GATT, Art.XXIII.2; 1979 Understanding, para.22; Annex, para.4. This has happened only once between 1948 and 1988 when in 1952 the Netherlands was authorised to impose a discriminatory quota on imports of wheat flour from the US following a dispute regarding US quotas on dairy products. The Netherlands did not retaliate: (1955) B.I.S.D., 3rd Supp. 46. Note that the authorisation may be blocked under the consensus rule.

28. GATT, Art.XXIII.2.

29. Jackson, op. cit. supra n.2, at p.184. 
the contractual balance of rights and obligations between the disputants in particular and among the contracting parties in general.

\section{Developing countries}

In $1966^{30}$ the Contracting Parties adopted a decision, confirmed in $1979,{ }^{31}$ which establishes the procedure to be followed for consultations and conciliation between developed and developing contracting parties.

This procedure provides, inter alia, for the Director-General of the GATT to employ his or her good offices with a view to facilitating a solution, for setting up a panel with the task of examining the dispute or problem in order to recommend appropriate solutions, and for time limits for the carrying out of the different parts of this procedure.

If the dispute is not resolved through consultations and conciliation, either party to it may refer the matter to the Contracting Parties. ${ }^{32}$

\section{Statistical data with respect to complaints and their disposal}

Statistical data compiled by the GATT Secretariat ${ }^{33}$ indicates that, in practice, most disputes concerning the interpretation or implementation of the GATT are settled through bilateral consultations without involving the Contracting Parties. This explains why between 1948 and 1986 only 104 complaints were made that formally invoked Article XXIII.2. Also, in some instances the contracting parties brought their disputes to the attention of the Council without reference to this provision.

Fifty-two of the 104 complaints resulted in the submission of a report by a panel. Of these reports 50 were adopted or led to a mutually satisfactory solution and hence a withdrawal of the complaint, or in two cases were implemented without adoption. It is only in two cases that the panel reports did not result in the resolution of the dispute. The other 52 complaints were settled during sessions of the Contracting Parties, by working parties, by groups of experts or through bilateral consultations before the panel had met. ${ }^{34}$

In 1987 seven panels were established and in 1988, 14. This recent increase in resort to the dispute settlement procedures of the GATT

30. (1966) B.I.S.D., 14th Supp. 18.

31. 1979 Understanding, paras.7-8. Annex, paras.2-3.

32. 1982 Ministerial Declaration on Dispute Settlement, para.(i).

33. This amounts to a 2.5 per year average. This section is based on FOCUS, GATT Newsletter, May 1987, No.46, p.2, Status Report End of 1986.

34. For a survey, see also R. E. Hudec, "Legal Issues in US-EC Trade Policy: GATT Litigation 1960-1985", in R. E. Baldwin, C. B. Hamilton and A. Sapir (eds.), Issues in US-EC Trade Relations (1988), p.17. 
seems to indicate that the contracting parties have more confidence in the quality of the work of the panels.

\section{B. The Tokyo Round Codes}

The non-tariff barriers agreements negotiated in the Tokyo Round also contain procedures for the settlement of disputes which apply only to GATT members having signed them. Some of them follow more or less the model of the 1979 Understanding. ${ }^{35}$ Others adopt new and more elaborate and rigorous procedures. ${ }^{36}$ Still others establish specific procedures although reference is made to Articles XXII and XXIII of the GATT.$^{37}$ Finally, some are without detailed procedures. ${ }^{38}$

The procedures are operated by the committee administering the agreement concerned. For instance, it is provided in the Code on Subsidies and Countervailing Duties that when a signatory believes that any subsidy granted or maintained by another signatory either causes injury to its domestic industry, nullification or impairment of benefits accruing to it under the GATT, or serious prejudice to its interests, such signatory may request consultations with such other signatory. In the event that no mutually acceptable solution is reached, the next step is conciliation mediated by the administering committee. Only then has the aggrieved party the right to a proceeding before a panel. The administering committee upon receipt of the panel report may make recommendations to the parties and if they are not followed within a reasonable period of time, authorise appropriate counter-measures. Strict time limits apply to each phase of the dispute settlement procedures. ${ }^{39}$

The dispute settlement procedures of the codes have been used sparingly. Between 1979 and 1986 three reports presented by panels established under the Code on Subsidies and Countervailing Duties were not adopted because they raised fundamental questions concerning the interpretation of certain articles of this code, on which the committee disagreed. ${ }^{40}$

35. Agreement on Technical Barriers to Trade (Standards Code); Agreement on Government Procurement; Agreement on the Implementation of Article VII of the General Agreement on Tariffs and Trade (Code of Customs Valuation).

36. Agreement on Interpretation of Articles VI, XVI and XXIII of the General Agreement on Tariffs and Trade (Code on Subsidies and Countervailing Duties); Agreement on Implementation of Article VI of the General Agreement on Tariffs and Trade (Revised Anti-Dumping Code).

37. Agreement on Trade in Civil Aircraft; Agreement on Import Licensing Procedures.

38. Bovine Meat Arrangement; Dairy Arrangement.

39. Arts.12, 13, 17, 18 .

40. Quoted from loc. cit. supra $n .33$. Note that if disputes arise between the parties relating to rights and obligations under the Revised Anti-Dumping Code, the parties should complete the dispute settlement procedures under the Code before availing themselves of any rights which they have under the GATT: Art.15, fn.14. 


\section{Criticisms of the Present System}

Dissatisfaction with the GATT procedures ${ }^{41}$ for the settlement of disputes results from a number of causes, especially the lack of automatic access to panels, delays in appointing them and in establishing their terms of reference, slow consideration of the cases due to the absence of strict time limits for the various stages of the procedure, an inadequate panel selection process, often a lack of competent and neutral panelists and the poor quality of panel reports. Decision-making by consensus, which allows blockage by the losing party, and difficulties and delays in implementing panel reports are also undermining the system.

A better system of surveillance to ensure compliance with recommendations and rulings is needed which ultimately depends upon the political will of GATT members to abide by the rules for the settlement of disputes. The lack of recourse available to the losing party has also been criticised.

Since the practice of the GATT has been to stress conciliation and negotiated settlements rather than the enforcement of obligations, ${ }^{42}$ recommendations or rulings are made only when the parties are unable to reach a mutually acceptable solution to their dispute. However, in recent years, especially since the $D I S C$ case,$^{43}$ the contracting parties seem to become more committed to the adjudicative process.

A more legalistic and rule-orientated procedure for the settlement of disputes would discourage the breach of the GATT rules, result in more precise decisions on the merits of disputes, and ensure greater compliance with them than does the present consensus system. Negotiated settlements favour countries that have considerable political and economic strength irrespective of the merits of the dispute. An adjudicative

41. For detailed analysis see e.g. R. E. Hudec, The GATT Legal System and World Trade Diplomacy (1975), Adjudication of International Trade Disputes (1978), and "GATT Dispute Settlement After the Tokyo Round: An Unfinished Business" (1980) 13 Cornell Int. L.J. 145; W. J. Davey, "Dispute Settlement in GATT" (1987) 11 Fordham Int. L.J. 51; K. R. Simmonds and B. H. Hill, Law and Practice under the GATT (1988); J. C. Bliss, "GATT Dispute Settlement Reform in the Uruguay Round: Problems and Prospects" (1987) 23 Stan. J. Int. L. 31; O. Long, Law and its Limitations in the GATT Multilateral Trade System (1985); E. McGovern, International Trade Regulation: GATT, The United States and the European Community (1986); US International Trade Commission, Review of the Effectiveness of Trade Dispute Settlement under the GATT and the Tokyo Round Agreements (1985); K. Dam, The GATT: Law and International Economic Organization (1970).

42. Long, idem, p.71: "In any proceedings, the Contracting Parties' main objective is to produce recommendations designed to protect this balance rather than have recourse to sanctions."

43. (1975-76) B.I.S.D., 23rd Supp. 98; J. H. Jackson, "The Jurisprudence of International Trade: The DISC Case in GATT" (1978) 72 A.J.I.L. 747; R. E. Hudec, "Reforming GATT Adjudication Procedures: The Lessons of the DISC Case" (1987-88) 72 Minn. L. Rev. 1443. 
approach stresses fairness and is more likely to protect the rights of small countries.

Perhaps greater use should be made of retaliation which, so far, has meant the re-establishment of the balance of concessions and advantages between the contracting parties concerned. Retaliatory measures should take the form of legal sanctions when the GATT rules have been broken. ${ }^{44}$ Unfortunately, a small country, especially if it is a developing country, has a limited capacity to retaliate against a major trading partner that fails to implement a panel recommendation.

The lack of agreement among the contracting parties on the nature of the panel rulings, whether they are binding on the parties to the dispute and constitute a precedent that can be relied upon in future disputes, has not enhanced the authority of the panels.

Although no one questions the view that the present system should be strengthened and made more effective, improvements will not be fully successful so long as some of the members of GATT are dissatisfied with the substantive rules adopted at Tokyo, especially with respect to subsidies. It is the lack of more rigorous substantive rules that has resulted in a strain on the legal remedies. ${ }^{45}$

Of the many suggestions that have been made to improve the present system, the following should be mentioned: a mechanism for early warning; notification to the Council of mutually agreed solutions where any GATT member could raise matters relating to such solutions; provision for going directly to the Council and requesting a panel should the other party fail to respond to a request for consultations within an established time period; the enhancement of the consultation, mediation and conciliation process, especially mediation by the Director-General; new options such as voluntary or mandatory binding arbitration to respond to the different nature of disputes, provided the rights of third parties are not affected; automatic access to panels; strict time limits for the Council when establishing panels; the creation of a permanent tribunal of legal experts or the holding of regular meetings of the Council devoted exclusively to dispute settlement; the use of standard terms of reference by panels; the expansion and the regular updating of a roster of non-governmental panelists; the imposition of strict time limits on the work of panels and the examination and implementation of their reports

44. Note that the GATT obligations could be enforced by resorting to traditional remedies under international law. However, the practice has been "to rely mainly upon the provisions of GATT itself for legal redress in cases of violation or other disputes", Jackson, loc. cit. supra n.2.

45. See R. E. Hudec, “' Transcending the Ostensible': Some Reflections on the Nature of Litigation Between Governments" (1987-88) 72 Minn. L. Rev. 221. According to the US International Trade Commission, op. cit. supra $\mathrm{n} .41$, the difficulties are not due to any serious defects in the dispute settlement mechanism per se but to the lack of political will on the part of the litigants to abide by GATT decisions. 
by the Council; the modification of the consensus rule, especially with respect to the adoption of the panel reports by the Council, by excluding the parties to the dispute from the decision-making process; the avoidance of differences of interpretation of the GATT rules by the panels; a more important role for the Secretariat and its legal staff; a better quality of government participation; an improved follow-up procedure; a clarification of the procedure in disputes involving several complainants; and the right of intervention of third parties, including access to information. Would their participation complicate and prolong the settlement of a dispute? In other words, should the right to make a complaint continue to be restricted to the countries directly concerned or be broadened?

Lastly, it has also been proposed that a special and more favourable treatment should be accorded to developing countries which would include specialised legal assistance, supplementary training courses and post-consultation review by the Council, so long as these measures do not infringe the principle of equality of treatment.

\section{THE IMPROVEMENTS OF THE URUGUAY ROUND}

\section{A. Introduction}

According to the Ministerial Declaration of 15 September 1986 signed at Punta del Este, the negotiating objectives of the Uruguay Round are as follows: $:^{46}$

In order to ensure prompt and effective resolution of disputes to the benefit of all Contracting Parties, negotiations shall aim to improve and strengthen the rules and the procedures of the dispute settlement process, while recognising the contribution that would be made by more effective and enforceable GATT rules and disciplines. Negotiations shall include the development of adequate arrangements for overseeing and monitoring of the procedures that would facilitate compliance with adopted recommendations.

From its inception, the Negotiating Group on Dispute Settlement was confronted with a large number of proposals made by the participating countries for the improvement of dispute settlement rules and procedures. ${ }^{47}$ These proposals enabled the Group to identify certain important issues for negotiations and to prepare the list of improvements that was submitted to the Trade Negotiations Committee meeting at the ministerial level in December 1988.

46. (1987) B.I.S.D., 33rd Supp. 19; GATT Newsletter, Jan.-Feb. 1987, No.43, p.6.

47. For some of these proposals see preceding section. 
The text adopted at the ministerial meeting ${ }^{48}$ begins with a declaration that the GATT dispute settlement system serves to preserve the rights and obligations of the contracting parties. It is a central element in providing security and predictability to the multilateral trading system. Existing rules and procedures will continue to be enforced but the improvements are to be applied on a trial basis only, from 1 May 1989 to the end of the Uruguay Round, in respect of Articles XXII and XXIII. The application of these improvements will also be kept under review during the remainder of the Round for the purpose of deciding on their permanent adoption. Meanwhile the Negotiating Group on Dispute Settlement will continue its work for the full achievement of the negotiating objectives.

\section{B. Notification}

Mutually agreed solutions to matters raised under Articles XXII.1 and XXIII.1 as well as arbitration awards within the GATT must be notified to the Council where any contracting party may raise any point relating thereto.

\section{Consultations}

A contracting party to which a request is made for consultations under Article XXII.1 or XXIII.1 must, unless otherwise mutually agreed, reply to it within ten days after its receipt and enter into consultations in good faith within a period of no more than 30 days from the date of the request, with a view to reaching a mutually satisfactory solution. If the requested party does not respond within ten days, or does not agree to enter into consultations within a period of no more than 20 days or any other period otherwise mutually agreed, from the date of the request, the complaining party may then proceed directly with a request for the establishment of a panel or working party. The purpose of this provision is to accelerate the procedures for the settlement of disputes when the offending party is not interested in reaching an amicable solution. If the consultations under Article XXII.1 or XXIII.1 fail to settle a dispute within 60 days after the request for consultations, the complaining party may request the establishment of a panel or working party under Article XXIII.2. This may also be done earlier if the parties jointly consider that consultations have failed to settle the dispute.

Any request for consultations must be in writing, contain the reasons for the request, and be notified to the GATT Council. Shorter time limits are set in cases of urgency. 


\section{Good Offices, Conciliation, Mediation}

Good offices, conciliation and mediation are voluntary procedures that may begin and be terminated at any time. The Director-General may, acting in an ex officio capacity, offer his or her services with the view to assisting the contracting parties to settle a dispute. This is important when developing countries are involved.

\section{E. Arbitration}

Although originally the GATT system did not provide for arbitration, the contracting parties to certain disputes that essentially concern issues that are clearly defined by them may now agree to settle them by expeditious, binding arbitration. The arbitration agreement must contain a selection of the arbitral procedure and be notified to all GATT contracting parties sufficiently in advance of the actual commencement of the arbitral process. One must assume that the procedure to be chosen by the parties could be governed by the 1985 UNCITRAL Model Law on International Commercial Arbitration ${ }^{49}$ or more likely the 1976 UNCITRAL Arbitration Rules. ${ }^{50}$ There is no need for a choice of law clause since the arbitration tribunal must apply the relevant GATT provisions.

The possibility of resorting to binding arbitration is one of the more interesting features of the improvements. It opens up new possibilities although one must not be over-optimistic since the panel system already operates as a quasi-arbitral tribunal. Although it is regrettable that the text does not provide for compulsory arbitration in some cases, this is understandable for it would have amounted to a major change in the GATT system of settlement of disputes for which the contracting parties were not ready.

Will the arbitration be ad hoc or will it be institutional? In the latter case, will it be administered by the GATT Secretariat exclusively or could it be administered by the International Chamber of Commerce, the American Arbitration Association or some other similar arbitral institution?

Other contracting parties are not affected by an arbitration and retain their rights under the GATT. However, they may become party to it upon the consent of the original parties.

Although the arbitration award does not require the approval of the Contracting Parties, it is probable that a party failing to implement the award will have to make compensation or face retaliation. Should the arbitral tribunal be limited to the remedies provided by the GATT

49. (1985) 24 I.L.M. 1302.

50. (1976) 15 I.L.M. 701. 
or should it be able to award damages? How and where would a monetary award be enforced against a losing party?

\section{F. Panel and Working Party Procedures}

The improvements made to the panel and working party procedures successfully remedy several of the criticisms addressed to them.

If the complaining party so requests, a decision to establish a panel or a working party must be taken at the latest at the Council meeting following that at which the request first appeared as an item on its regular agenda. The ministers did not give the contracting parties a legal right to a panel.

Standard terms of reference are applicable unless the parties to the dispute agree otherwise. Panels shall be composed of well-qualified governmental or non-governmental individuals or both. In this connection the roster of non-governmental panelists is to be expanded and improved. In principle, a panel is composed of three members, unless the parties to the dispute agree within ten days from the establishment of the panel, to a panel composed of five members. If there is no agreement on the members of the panel within 20 days of its establishment, each party may request the Director-General in consultation with the Chairman of the Council to form the panel. ${ }^{51}$ These procedures do not differ greatly from those followed by arbitral institutions. They may render GATT arbitration less attractive especially if the adoption and implementation of recommendations and rulings are made more effective.

Special procedures are adopted for multiple complainants. Thus, a single panel may be established to examine several complaints related to the same matter.

Provision is also made for third party practice. Any third contracting party having a substantial interest in the matter before a panel, and having notified this to the Council, shall have an opportunity to be heard by the panel and to make written submissions to it. The panel may also grant the third contracting party access to the written submissions to the panel by those parties to the dispute which have agreed to the disclosure of their respective submissions to the third contracting party.

With respect to the various phases of a panel, it is recommended that the panels follow the suggested working procedures found in the July 1985 Note of the Office of Legal Affairs, unless the members of the panel agree otherwise after consulting the parties to the dispute. As a general rule, the period in which the panel shall conduct its examination from the time the composition and terms of reference of the panel have

51. Ten days shorter than previously. See 1984 Decision, para.3. 
been agreed upon to the time when the final report is provided to the parties to the dispute, shall not exceed six months and, in cases of urgency, the panel shall aim to provide its report within three months as is the case pursuant to the 1979 Understanding. ${ }^{52}$ Since panel procedures should provide sufficient flexibility to ensure high-quality panel reports while not unduly delaying the panel process, no compulsory time limits are fixed. However, it is stated that in no case should the period from the establishment of the panel to the submission of the report to the contracting parties exceed nine months. This is stronger language than that found in the Annex to the 1979 Understanding. ${ }^{53}$

\section{G. Adoption of Panel Reports}

In order to provide sufficient time for the members of the Council to consider panel reports, such reports shall not be considered for adoption until 30 days after they have been issued to the contracting parties. During that time the disputants may still be able to settle their differences. Contracting parties having objections to a panel report must give written reasons to explain their objections for circulation at least ten days prior to the Council meeting where the report will be considered.

On the controversial question of consensus, it is reiterated that the parties to a dispute have the right to participate fully in the consideration of the panel report by the Council and that their views shall be fully recorded. Panel reports are still to be adopted by consensus without prejudice to the GATT provisions on decision-making which remain applicable. However, the parties to a dispute shall not avoid delaying the process of dispute settlement. The ministers shied away from declaring that the parties to a dispute may either join or abstain from the consensus or even be excluded from it. Thus, blocking of remedial measures is still possible.

The period from the request under Article XXII.1 or XXIII.1 until the Council makes a decision shall not, unless the parties agree otherwise, exceed 15 months.

\section{H. Technical Assistance}

The technical assistance services of the GATT Secretariat in respect of dispute settlement are available to any contracting party requesting them. Legal advice and assistance by a qualified expert within the Technical Co-operation Division may also be obtained by any developing contracting party. Training courses for interested contracting parties 
concerning the GATT dispute settlement procedures and practices will be conducted by the Secretariat.

\section{Surveillance of Implementation of Recommendations and Rulings}

Prompt compliance with recommendations and rulings of the Contracting Parties under Article XXIII.2 is declared to be essential in order to ensure effective resolution of disputes. There is an obligation on the part of the contracting party concerned to inform the Council of its intention in respect to implementation of the recommendations or rulings. If that party finds it impracticable to comply immediately with the recommendations or rulings, it shall have a reasonable period of time in which to do so.

The Council shall monitor the implementation of recommendations or rulings. Thus, unless the Council decides otherwise, this issue shall be on the agenda of the Council meeting after six months following the adoption of the recommendations or rulings and shall remain on the agenda until it is resolved. Also, at least ten days prior to each such Council meeting, the contracting party concerned shall provide the Council with a status report in writing of its progress in the implementation of the panel recommendations or rulings. The purpose of these improved procedures is to encourage the losing party to remove the offending measure as promptly as possible.

The ministers did not settle the issues of the definition, determination and types of compensation should the offending party fail to implement the recommendations or rulings, nor did they consider the amount of impairment that could serve as a guide to negotiate compensation or as a basis for the suspension of concessions or other obligations. Panels should be able to recommend the payment of damages as a form of compensation. The determination of the date from which the calculation of the amount of impairment is to be made is another important question. Perhaps these issues will be dealt with by the Negotiating Group on Dispute Settlement before the end of the Uruguay Round.

\section{CONCLUSION}

THE improvements of the GATT dispute settlement rules and procedures are very modest and to some extent of a cosmetic nature. They do not evince a definite political commitment to settle trade disputes by these new rules and procedures and to abide by the results. This is made clear by the refusal to adopt the "consensus-minus-two" rule. Panel decisions are not yet fully binding and enforceable. Emphasis is still placed on a flexible system of negotiated settlements and consensus. The most important innovations are the adoption of arbitration as an 
alternative means of dispute settlement and the shorter time limits applicable to the various phases of a panel. Much remains to be done in the future. A truly adjudicative and legalistic system of settlement of disputes is not yet in sight. 